Egyptian Journal of Rabbit Science, 27 (2): 171- 195(2017)

\title{
THE ROLE OF NUTRITION IN IMMUNITY AND DISEASES RESISTANCE IN RABBITS
}

\author{
M.I.Abd El-Rahim
}

Animal \& Poultry Production Department, Faculty of Technology \& Development, Zagazig University,Zagazig, Egypt

Email: mostafarahim@ymail.com

\section{ABSTRACT}

All animals protect themselves from invasion of microbes, parasites, fungi, viruses and any foreign molecules. This protective capacity is based on effective immune system which is considered an important factor for animal health.

Enteric diseases frequently occur in rabbits, more especially in young rabbits after weaning. These digestive troubles cause mortality and reduced growth rates with important economic losses.Antibiotics are frequently used to prevent or to treat such illness.Unfortunately, the long term and extensive use of antibiotics has led to appearance strains of bacteria resistant to the antibiotics and caused adverse effects on the consumer health. So, it is necessary to search about alternatives to antibiotics.

One of the possible preventive approaches is to improve the nonspecific immunity resistance of rabbits through the improvement of nutrition.Nutrition is also an important factor for rabbits to deal with environmental and psychological stressors such as heat, cold and inappropriate husbandry practices.A number of micronutrients and feed additives have been shown to affect various aspects of immunity in rabbits. Insufficient contents of micronutrients in animal diets are related with low disease resistance. A balanced supply of micronutrients such as vitamins $E, \beta$-Carotenoids, Vitamin A, Vitamin $C$ and the trace elements zinc $(\mathrm{Zn})$, Copper $(\mathrm{Cu})$, selenium $(\mathrm{Se})$, Manganese (Mn), Cobalt (Co), Iron (Fe)isof great importance for proper functioning of host defense mechanism.Some feed additives such as probiotics, prebiotics, enzyme preparations and organic acids could improve the immune response and disease resistance in rabbits.

Nutrients have direct role on immunity as they serve as substrates and enzymes cofactors for cellular multiplication during immune response (phagocytes, lymphocytes)and for synthesis of effective molecules (antibody, complement, nitric oxide, lysozyme)or informant molecules (cytokines, inflammatory mediators; Klasing and 
Leshchinsky, 2000 ). Amino acids, fatty acids and glucose serve as susbtrates, while vitamins and minerals act as co-factors for enzymatic activities. Nutrients could also have an indirect effect on immune response by modifying the intra- and extra-cellular communication pathways (cytokines) or limiting undesirable effects of effective molecules. Finally, the immune system is also regulated by numerous hormones (gastrin-releasing peptide, GH, IGF1, insulin, thyroids hormones...) most of which are responsive to nutritional factors (glucose, protein/energy ratio).

The amount of studies done on the effect of nutrition on immune function in rabbits are very little, so it is difficult now to propose actual dietary values for stimulating the immune defense of rabbits. However, the nutritionists can use the available data of fiber, fats (namely the quantity and nature of fatty acids), vitamin $E$ and selenium and the interaction between them to offer the most interesting in this concern. The work should concentrate on the rabbit at weaning time, because this is the most critical period for young rabbits to infect by digestive diseases.

Key words:Nutrition, immunity response,rabbits, antibiotics, diseases resistance, micronutrients, feed additives.

\section{INTRODUCTION}

One of the most important changes in farm animals husbandry over the past 30 years is the shift from disease treatment towards disease prevention.Enteric diseases frequently occur in rabbits, more especially inyoung rabbitsafterweaning. These troubles cause mortality and reduced growth rates with importanteconomic losses. Within the same breed, digestive system diseases are the most important cause of mortality which represents about $12-24 \%$ in rabbit farmsbetween birth and marketing (Peeters, 1988 and Rashwan and Marai, 2000). Antibiotics are frequently used to prevent or to treat such illness. Unfortunately, the long term and extensive use of antibiotics has led to appearancestrains of bacteriaresistant to the antibiotics and caused adverse effects on the consumer health. So, it is necessary to search about alternatives to antibiotics (Forthun-Lamothe et al., 2002, Eiben et al, 2008, Millet and Maertens, 2011, Seal et al., 2013, Stanton, 2013and Guyue Cheng et al., 2014).One of the possible preventive approaches is to improve the non-specific immunity resistance of rabbits through the improvement of nutrition (Forthun-Lamothe, 2004,Fekete and Kellems, 2007, Attia et al., 2013 and Batta et al., 2014). Nutrition is considered one of an important immunity modulating agentsin rabbits. 
The mucosa of the small intestine has a major role in the digestion and absorption of nutrients and represents an important area of defense against antigenic aggressions in young rabbits (Forthun-Lamothe et al., 2004 and Gallois et al., 2005).The ability of gut mucosal immune functions depends on adequate nutrition for nutrient absorption (Carabano and Piquer, 1998 and Csiro, 2001). Nutrition is also an important factor for rabbits to deal with environmental and psychological stressors such as heat, cold and inappropriate husbandry practices. Adrenal glands in the rabbit control cecotrophy (ingestion of soft feces) and stress affects adrenal gland functioning. Increased stress results in increased adrenal activity that will slow or stop digestive processes important to cecotrophy. Cecotrophy provides a rabbit withvitamins, protein and volatile fatty acids (VFA) that are essential to the nutritional status and the health of a rabbit. Researchindicates that altering some dietary constituents in a rabbit ration may compensate for the increased metabolic demand caused by stress (Csiro, 2001).

The following review examines the recent advances in understanding the relationship betweennutrition and immunity in rabbits as well asverifies the effects of nutrients and some feed additives on the immune response and diseases resistance.

\section{The Immunity:}

All animals protect themselves from invasion ofmicrobes, parasites, fungi, viruses and any foreign molecules. This protective capacity is based on effectiveimmune system which is considered an important factor for animal health (Drouet-Viard and Fortun-Lamothe, 2002 and Fekete and Kellems, 2007).

Immunity refers to ability of the body through its own immunity system to protect itself against specific pathogens or antigens and foreign molecules (The resistance against infection or disease).A group of organs, cells and molecules that protect the body against infection, malignancy and damaged cells is called immune system. The immune system is divided into innate (natural) or non-adaptive immune system and the acquired or specific or adaptive immune system.

\section{A. Innate (Natural) or non-adaptive or nonspecific immunity:}

Innate immunity is composed of physical barriers against infection (skin, mucous membranes in respiratory and other systems, saliva, and physical reflexes such as coughing, sneezing, tear production, inflammation, fever, phagocytic cells (neutrophils, macrophages, and natural killer cells),cytokines and acute-phase proteins. 


\section{B. Acquired (Adaptive) or specific or adaptive immunity:}

Adaptive immunity can be divided into two categories i.e. humoral and cell mediated immunity. The cells of the acquired immune system are responsible for synthesizing antibodies and killing the invading microbes.

\section{Humoral immunity:}

Humoral immunity is that type of immune protection that can be transferred by blood serum. It includes antigen receptors called immunoglobulin, or antibodies that are attached to the surface of Bcells(Fortun-Lamothe L. and Drouet-Viard F. 2002). B-cells develop in the bone marrow or fetal liver and differentiate into antibody-producing plasma cells. They recognize antigens by their surface immunoglobulin. In order to produce an antibody response, most B-cells require the presence of an antigen (T-dependent antigen) together with help from antigen-specific $\mathrm{T}$ cells.

\section{Cell mediated immunity:}

Cell mediated immunity is associated with T-cells. T- cells differentiate in the thymus and function to: 1- help B- cells make antibodies.2- kill virusinfected cells.3-regulate the level of immune response.4-stimulates the microbicidal and cytotoxic activity of other immune effector cells, including macrophages.

$\mathrm{T}$-cells recognize antigen and $\mathrm{MHC}$ molecules via a receptor molecule. There are three main types of T cells: (i) helper T- cells CT,). These cells are stimulated by a combination of an antigen and an MHC Class II molecule found on the surface of an antigen-presenting cell. An antigen-presenting cell is one which is capable of presenting an antigen to lymphocytes in an immunogenic form. Helper $\mathrm{T}$ - cells interact with $\mathrm{B}$ cells to produce antibodies, are involved in the maturation of cytotoxic T- cells, and interact with other cells (e.g. macrophages) by secreting lymphokines; (ii) suppressor T- cells CT; (iii) cytotoxic T- cells CT.

Immune deficiency may be congenital, genetic and acquired. The latter can be caused by virus infection (human and cat HIV), ingestion of certain mycotoxins (e.g. T-2 toxin, Fekete et al., 1989), peroxides of rancid feed (Fekete and Kellems, 2007), long-lasting stress and corticosteroid treatment. Immune deficiency increases susceptibility against infections.

\section{Effect of nutrients and feed additives on immunity response and diseases resistance:}

The nutritional status of animal is dependent on dietary intake and effectiveness of themetabolic processes.Many nutrients, including some 
that are not essential for growth or reproduction, regulate and modify immune responses(McWilliams, 2001).

For many of essential nutrients, deficiencies that are sufficiently sever to slow growth or reproduction are also deleterious to the adaptive immune system and markedly increase susceptibility to pathogens( Kidd, 2004 and Korver, 2012).leukocytes are among the most sensitive to marginal deficienciesfor some nutrients, while for other nutrients the immune system is largely unaffected by deficiencies. This variation can be explained by several mechanisms. Firstly, most leukocytes in healthy animals are exceptionally inactive and have very low nutrientneeds. Secondly, many lineages of leukocytes have an excellent capacity to compete with other cellswhen circulating levels of nutrients are low. This high priority for nutrients is greatly enhanced inthose cells that respond to an infectious challenge. Thirdly, an immune response is accompanied bythe mobilization of nutrients from muscle and other tissues, which supplies adequate amounts of some, but not allnutrients to leukocytes.

\section{Mechanisms of nutritional effects on immunity:}

The mucosa of the small intestine has a major role in the digestion and absorption of nutrients and represents an important area of defense against antigenic aggression in young rabbits (Cunningham et al, 2005 and Gallois et al., 2005).

Nutrients have direct role on immunity as they serve as substrates and enzymes cofactorsfor cellular multiplication during immune response (phagocytes andlymphocytes)and for synthesis of effective molecules (antibodies, nitric oxide and lysozymes)or informant molecules (cytokines and inflammatory mediators; Klasingand Leshchinsky, 2000). Nutrients act as substrates are mainly amino acids, fatty acids and glucose, while those act as co-factors for enzymatic activities are often vitamins or minerals. Nutrients could also have an indirect effect on immune response by modifying the intra- and extra-cellular communication pathways (cytokines) or limiting undesirable effects of effective molecules. The amount and profile of fatty acids in the diet determine the type of fatty acids which are incorporated into the cell membranes and hence the fluidity of the membranes and the type of eicosanoid secreted as informant molecules. Certain anti-oxidants (vitamins E, Cand $\beta$-carotene) may limit the undesirable effects of destructive molecule (nitric oxide and hydrolases) on membraneous components (phospholipids). Finally, the immune system is also regulated by numerous hormones (gastrin-releasing peptide, GH, IGF1, insulin and thyroids hormones) most of which are 
responsive to nutritional factors (glucose andprotein/energy ratio; Gentonand Kudsk, 2003).

Proteins and amino acids: Most of the inflammation and immune reaction mediators are peptides (cytokines, immuno-globulins, complement proteins, DNA synthesis for lymphocytes proliferation). These proteins present a very different profile from proteins involved in the body growth or milk production. This leads to specific amino acidrequirements for the immune response that confers a key role tolevel (quantity) and quality (amino acids) of proteins in the diet to optimize immuneresponse. Immuno-modulatory role of arginine and glutamine have been demonstrated and discussed (Evoy et al., 1998; Redmond et al., 1998; and Lai et al., 2004), but specific recommendations for amino acids to optimize immune response in rabbits are not known.

Dietary fiber (Crude fiber): It is a mixture of cellulose, lignin, cutin and suberin. The digestibility of dietary crude fiber by rabbitsvaries from $60 \%$ to $80 \%$ and this negatively correlated with lignin content and depends on microbial activity and digesta retention time in the cecum.

Rabbits on a low fiber diet develop a change in GIT $\mathrm{pH}$ that will kill symbiotic bacteria, and the loss of bacteria may result in an increase in pathogenic organisms like Clostridia sp. and E. coli that cause disease states in rabbits (McWilliams, 2001). Other opportunisticpathogens include coccidia like Eimeria perforans (E. perforans), E. magna E. piriformis, E. intestinal is E. flavescens, E. irresidua and E. media. E. coecicola and E. exigua are also intestinal coccidia but are not pathogenic. The rabbit stomach normally has a very low $\mathrm{pH}$ (1 to 2 ) that effectively kills pathogenic microorganisms. Weanling rabbits have a stomach $\mathrm{pH}$ of 5 to 6.5 and weanling diarrhea develops because this stomach $\mathrm{pH}$ is not acidic enough to destroypathogenic microbes. Weanlings, however, must go through this period of a higherstomach $\mathrm{pH}$ to allow the growth of symbiotic microbial populations in the gut.Adequate fiber is an important nutritional factor in diseases prevention caused by opportunistic pathogens (McWilliams, 2001).

Normal functioning of the rabbit cecum is dependent on dietary fiber. Without sufficient dietary fiber, the proximal colon absorbs too much liquid and this prevents digesta particles refluxing back to the cecum (Gidenn, 2000). This results in a loss of nourishment forthe normal bacteria in the cecum and allows growth of opportunistic pathogens.Cecal impaction results when a decrease in dietary fiber increases retention timeand there is a digesta build-up in cecum. The accumulated digesta is retained and aprolonged fermentation results that produces bloat. The $\mathrm{pH}$ of the cecum 
isalso altered and destroys symbiotic bacteria and allows the growth of pathogens like Clostridium spiriforme (Clostridium spiriforme proliferation) that result in enterotoxemia (carbohydrate overload of the hindgut or starch overload theory).Rabbits on high carbohydrate diets often develop enterotoxemia because the excess carbohydrates in the cecum change the normal acidic $\mathrm{pH}$ (1 to 2) to $\mathrm{pH} 6$ favorable to thedevelopment of Clostridia sp. and E. coli (Gidenn and Pinheiro, 1998 and Remois et al, 2000).The digestive capacity for starch is very low in young rabbit before 25 days of life and sharply increase thereafter (Debray et al., 2003).Some authors hypothesized that the intake of diet rich in starch could exceed the intestinal enzymatic capacities of young rabbits, and the overflow of starch entered the caecum could impair the establishment of a balanced microbial ecosystem (Pinheiro and Gidenne, 2000 and Fortun-Lamothe and Boullier, 2004).

Colibacillosis disease is also develops when there is adeficiency in dietary fiber and the gut $\mathrm{pH}$ is altered. It consists of mild to severe yellowdiarrhea, anorexia and fever. Colibacillosis is a form of enteritis caused when E. colimultiply in the altered gut substrate. Colibacillosis is often seen with intestinalcoccidiosis and the two pathogens produce a virulent synergy and are more lethaltogether than alone (Remois et al, 2000).

\section{Lipids and fatty acids.}

The amount and type of dietary fat can modulate immune function both at systemic (Calder, 1998, Koskiet al, 1999, De Cuypere and Dierick, 2003 and Yaqoob, 2003) and intestinal levels (Miura et al., 1998). Fatty acids are structural components of cells membranes and precursors for the synthesis of eicosanoids (includes leukotriene, prostaglandins and inflammation mediators molecules). Both excess and deficiency of them could be harmful to immune system (Calder, 2006). Fat absorption could also influences indirectly the mucosa immune system byincreasing cytokine release from intestinal epithelial. The quality of fatty acids has an effect on immune system,more especially the level of polyunsaturated fatty acids of the $\omega 6$ or $\omega 3$ series (fatty acids with double bonds, the first of which being on atom carbon 6 or 3 , respectively, from the methyl end) seems of primary importance for immunomodulation. The metabolism of $\omega 6$ or $\omega 3$ series fatty acids is competitive because metabolic pathways of elongation or desaturation use the same set of enzymes. The major end products of $\omega 6$ and $\omega 3$ pathways are respectively arachidonic acid (precursor of leukotriene) and decosapentaneoic acid (Ziboh, 2000). Arachidonic acid from $\omega 6$ fatty acids leads to production of pro inflammatory eicosanoids (LT4 and PGE2). These pro-inflammatory 
molecules induce beneficial immune reactions by playing an immunoregulatory role, but can also leads to harmful reactions if they are mobilized intensely, reducing production of cytokines. Metabolism of $\omega 3$ fatty acids could counterbalance these negative effects by formation of less biologically active leukotriene (LT5; Chapkin et al., 2000).An excess of lipids also alter the immune response by reducing proliferation of lymphocytes, production of cytokines and activity of NK cells and phagocytosis (Calder, 1998 and Pablo and Cienfuegos, 2000).

\section{Macrominerals:}

Macrominerals are needed by rabbits in relatively large amounts for growth and maintenance of bone structure, muscle contractions, cellular nutrientabsorption and salt balance. The macrominerals for rabbits are calcium, phosphorous, magnesium, potassium, sodium and chlorine.

Calcium and phosphorus are major components of the skeletal system. Calcium plays a key role in organic processes, such as heart function, muscle contraction, coagulation and electrolyte equilibrium of the blood. Phosphorus is also involved in energy metabolism. Rabbits are quite unique in the metabolism of calcium. Calcium is absorbed in the direct proportion to its concentration in the diet, regardless of the metabolic need. Excess calcium is eliminated through the urine. This accounts for the chalky white deposits seen beneath the cages. A dietary ratio of calcium to phosphorus of $1.5: 1$ to $2: 1$ is recommended. An excess of calcium $(>15 \mathrm{~g} / \mathrm{kg})$ increases the calcification of soft tissues and can reduce the absorption of phosphorus and zinc, which will lead to deficiencies in those minerals. An excess of dietary phosphorus $(>9 \mathrm{~g} / \mathrm{kg})$ may reduce feed intake and reduce fertility (De Blas and Wiseman, 2010). Legumes are high in calcium and grains are good sources of phosphorus. A combination of both grains and alfalfa will generally meet the calcium and phosphorus needs of the growing rabbit. Rabbit milk is very rich in both minerals, thus lactating does have higher requirements of both elements than growing or non-lactating does. Rabbit milk contains on average three to five times more calcium and phosphorus than cow's milk (DeBlas and Wiseman, 2010). At maximum milk production a doe can excrete up to $2 \mathrm{~g}$ of calcium.

Magnesium $(\mathbf{M g})$ :In rabbits, magnesium is a major component of the bones ( 0.7 of total body magnesium is in theskeleton) and also acts as a cofactor in many energy metabolism reactions. $\mathrm{Mg}$ deficiency results in poor growth, alopecia,hyperexcitability, convulsions, loss of fur texture and fur chewing. Any dietary excess of $\mathrm{Mg}$ is excreted through the urine. 
$\mathrm{Mg}$ is usually available in sufficient quantities in commercial rabbit feeds (DeBlas and Wiseman, 2010).

Potassium (K): Potassium plays a key role in the regulation of the acidbase balance in organisms and is a cofactor of numerous enzymes. Symptoms of deficiency include muscle weakness, paralysis and respiratory distress. Potassium ion $(\mathrm{K}+)$ deficiency in rabbits might appear when diarrhoea is present (Lebas,2004).

Sodium (Na): Sodium is involved in the regulation of $\mathrm{pH}$ and osmotic pressure. Sodium is essential for the absorption of luminal nutrients such as glucose and amino acids(DeBlas and Wiseman, 2010). A deficit in Na+ may impair the efficiency of digestive processes and/or the absorption of amino acids. Chamorro et al. (2007) observed that a reduction in $\mathrm{Na}+$ from 2.6 to $1.6 \mathrm{~g} \mathrm{~kg}-1$ impaired ileal digestibility of methionine and cystine, although dry matter and protein digestibility were not affected.Excess $\mathrm{Na}+$ in the feed $(>8-10 \mathrm{~kg}$ sodium chloride $(\mathrm{NaCl}) \mathrm{kg}-1 \mathrm{diet})$ or the presence of salt in the drinking water $(3000 \mathrm{mg} \mathrm{kg}-1)$ is detrimental to growth (Marai et al., 2005).

Chloride $(\boldsymbol{C l})$ : Chloride is also involved in acid-base regulation. In addition, this ion concentrates in the gastric cells. It is secreted as hydrogen chloride and is involved in the solubility of mineral salts and protein digestion.The relationship between $\mathrm{Na}+, \mathrm{K}+$ and $\mathrm{Cl}-$ (the electrolyte balance)affects animal performance and influencing on resistance to thermalstress, leg score, kidney function and incidence of milk fever (Chiericato and Rizzi (2004).

Micronutrients (Trace elements and vitamins): Several trace minerals having great importance in immunity: zinc, copper, selenium, manganese, cobalt and iron (Scrimshaw and Sangiovanni, 1997 and Erickson et al, 2000). Nearly all the vitamins are involved in the functions of the immune system cells: phagocytosis, synthesis of molecules, regulating the leucocytic function (interleukins) and production of immuno-globulins (Kolb, 1997). Consequently, a deficiency of certain vitamins reduces production of antibodies, phagocytosis and destruction of the infected cells.

In many animal species, the requirements for certain vitamins (A, D and E) and trace minerals to maintain optimum immune function are much higher than that for adequate growth (Klasing and Leshchinsky, 2000, Fekete and Kellems, 2007 and Shyam and Avijit,2015). 
Subclinical or marginal deficiencyrepresents a larger problem than acute mineral deficiency because specific clinical symptoms are not evident to allow the producer to recognize the deficiency. So, subclinical trace mineral or vitamins deficiency will adversely affect immunity, reproduction and growth before clinical deficiency symptoms are observed (Fortun-Lamothe and Boullier, 2004).

Zinc (Zn): Zinc is reported to be a cofactor for more than 300 different enzymes that modulate many physiological processes (Carroll and Foresberg, 2007).Zinc is known to play a central role in the immune system.Zinc deficiency decreases resistance to infectious diseases. The immunologic mechanisms whereby zinc modulates increased susceptibility to infection have been studied for several decades.Zinc affects multiple aspects of the immune system, from the barrier of the skin to gene regulation within lymphocytes. Zinc is crucial for normal development and function of cells mediating nonspecific immunity such as neutrophils and natural killer cells.Zinc deficiency also affects development of acquired immunity by preventing both of the outgrowth and certain functions of $\mathrm{T}$ lymphocytes such as activation, cytokine production, and B lymphocyte help. Likewise, B lymphocyte development and antibody production, particularly immunoglobulin G, is compromised. The macrophage, a pivotal cell in many immunologic functions, is adversely affected by zinc deficiency, which cans dysregulate intracellular killing, cytokine production, and phagocytosis.Zinc is component of numerous enzymes: Superoxide dismutase (SOD), RNA polymerase, DNA polymerase, Ribonuclease, Thymidine kinase. The copper- and zinc-containing superoxide dismutase (SOD1) protects eukaryotic cells against oxidative stress by scavenging toxic superoxide anions. Zinc also is an important cofactor in DNA synthesis and gene transcription (Fraker et al., 2000).

Copper (Cu): Copper is needed for proper development and maintenance of the immune system,including the formation of antibodies and white blood cells. Copper deficiency results in decreased humoral and cell-mediated immunity, as well as decreased nonspecific immunity (Erickson et al., 2000; Schrimshaw and Sangiovanni 1997 and Carroll and Forsberg 2007). Dietary $\mathrm{Cu}$ affects phagocytic as well as specific immune function regulated by phagocytic cells such as macrophages and neutrophils. Two copper-dependent enzymes, ceruloplasmin and superoxide dismutase, exhibit anti-inflammatory activity and may play critical roles in the prevention of oxidative tissue 
damage resulting from infection and inflammation. Copper is involved in the antioxidant system via its involvement in the enzymes $\mathrm{Cu}-\mathrm{Zn}$ superoxide dismutase (SOD). SOD is considered the first line of defense against pro-oxidants. It has been assumed that SOD has a central role in the defense against oxidative stress.

Iron (Fe): The most profound changes associated with low iron levels are the reduction of peripheral T-cells, impairment of phagocyte, natural killer activities, lymphocyte interleukin-2 production, decreased delayed type hypersensitivity and the thymus atrophy. Iron deficiency anemia was found to have impaired neutrophil bactericidal activities and cell mediated immune functions which were reversible with adequate iron therapy (Oppenheimer, 2001).

Selenium (Se) and Vitamin E: Selenium is an anti-oxidant that works in conjunction with Vitamin $\mathrm{E}$ to prevent and repair cellular damage in the body. Selenium and/or Vitamin E deficiency has been shown to impair immune response. Selenium is also associated with thyroxine, a thyroid hormone that regulates metabolism, reproduction, circulation and muscle function. Selenium also protects the body from heavy metals by forming complexes to render them harmless. The antioxidant roles of vitamin $\mathrm{E}$ and selenium, via the metalloenzyme glutathione peroxidase, share common biological activities. The sparing of one will impact the functionality of the other. Selenium acts as an essential component of the enzyme Glutathione peroxidase, which destroys $\mathrm{H}_{2} \mathrm{O}_{2}$ and lipid hydroperoxides.Vitamin $\mathrm{E}$ protects the cell membranes from peroxyl radicals produced from polyunsaturated fatty acids(PUFA) and yield stable lipid hydroperoxide, which is harmless (Pinelli , 2003 and Broome et al, 2004).

Cobalt and Vitamin B12: Cobalt is essential in ruminant diets for the synthesis of vitamin B12. Cobalt may also be beneficial in herbivorous diets as a means of improving the efficiency of fiber digestion by bacteria. Limited research indicates that Co deficiency affects neutrophil function and resistance to parasitic infection. Vitamin B12 play central role in immune processes because it governs cell division and growth. Without adequate B12, white blood cells can't mature and multiply. Vit.B12 decreased white blood cell response and shrinkage of the critical immune system organ (Scrimshaw and Sangiovanni, 1997).

Vitamin $\boldsymbol{A}$ and $\boldsymbol{\beta}$-carotene:Integrity of the epithelial lining of mucosal surfaces with its mucus covering constitutes the major limb of the innate 
immune responses and is essential to prevent microbial invasion. Loss of integrity of the epithelial lining of mucus membranes in a vitamin A deficient state explains its close association with increased susceptibility to infections particularly of gastrointestinal, respiratory and genitourinary tracts. The xerotic surfaces form potential sites for increased bacterial adherence, thus leading to bacterial colonization. The antimicrobial enzyme lysozyme depends on vitamin A for its synthesis. These effects were attributed to impairment of lymphoid cellular proliferation and differentiation of primary lymphoid organs. B-Carotene is the major precursor of vitamin A that occurs naturally in feedstuffs. Research suggests that $\beta$-carotene may affect immune function, independent of its role as a source of vitamin A. $\beta$-Carotene, as such, can serve as an antioxidant, while vitamin $\mathrm{A}$ is not an important antioxidant (Kerti et al, 2005).

Vitamin $C$ : As an antioxidant, Vitamin $\mathrm{C}$ is an excellent source of electrons; therefore, it "can donate electrons to free radicals such as hydroxyl and superoxide radicals. Supplementation of vitamin C improves components of the immune system such as antimicrobial and natural killer (NK) cell activities, lymphocyte proliferation, chemotaxis and delayedtype hypersensitivity. Vitamin $\mathrm{C}$ acts against the toxic, mutagenic and carcinogenic effects of environmental pollutants by stimulating liver detoxifying enzymes. Vitamin $\mathrm{C}$ contributes to maintaining the redox integrity of cells and thereby protects them against reactive oxygen species generated during the respiratory burst and in the inflammatory response (Kolb, 1997). In the rabbit, the cecal flora synthesizes large amounts of water-soluble vitamins which are rendered available by caecotrophy. It is generally agreed that all the vitamin requirements of group $\mathrm{B}$ and $\mathrm{C}$ are met in this species. However, the course of caecotrophy is frequently disturbed in the sick animal, especially in the case of digestive disorders such as enteritis. In this case, a deficiency of vitamins of B group and of vitamin $\mathrm{C}$ could arise, lowering the resistance to attack and delaying recovery. Therefore, supplementation of vitamins $\mathrm{B}$ and $\mathrm{C}$ could be of interest during infectious episode knowing that the risk of poisoning from an excess of these vitamins seems to be slight (Lebas, 2000). Table 1 and 2 represent the effect ofsome mineralsand vitaminson immuneresponse. The data in Table 3 show the recommended dietary mineral concentrations for rabbits of different physiological status, while the data in Table 4 indicate therecommended dietary vitamin levels for rabbits. 
Table 1. The effect of some minerals on immune response (from Scrimshaw and Sangiovanni, 1997).

\begin{tabular}{|l|l|l|l|l|l|}
\hline Immune response & Zn & Cu & Mg & Fe & Se \\
\hline Humoral mediated response, B & $\times$ & $\times$ & $\times$ & $\times$ & \\
lymphocytes & & $\times$ & $\times$ & $\times$ & $\times$ \\
Cell -mediated response, T & $\times$ & $\times$ & $\times$ & $\times$ & \\
lymphocytes & $\times$ & $\times$ & & $\times$ & $\times$ \\
Immunoglobulins & $\times$ & $\times$ & $\times$ & $\times$ & $\times$ \\
Thymus (Structure or function) & $\times$ & & $\times$ & $\times$ & $\times$ \\
Phagocytes function & $\times$ & $\times$ & $\times$ & $\times$ & $\times$ \\
Killer cells & & & & & \\
Cytokines or Lymphokines production & & & & & \\
\hline
\end{tabular}

Table 2. The effect of vitamins on immune response (from kolb, 1997).

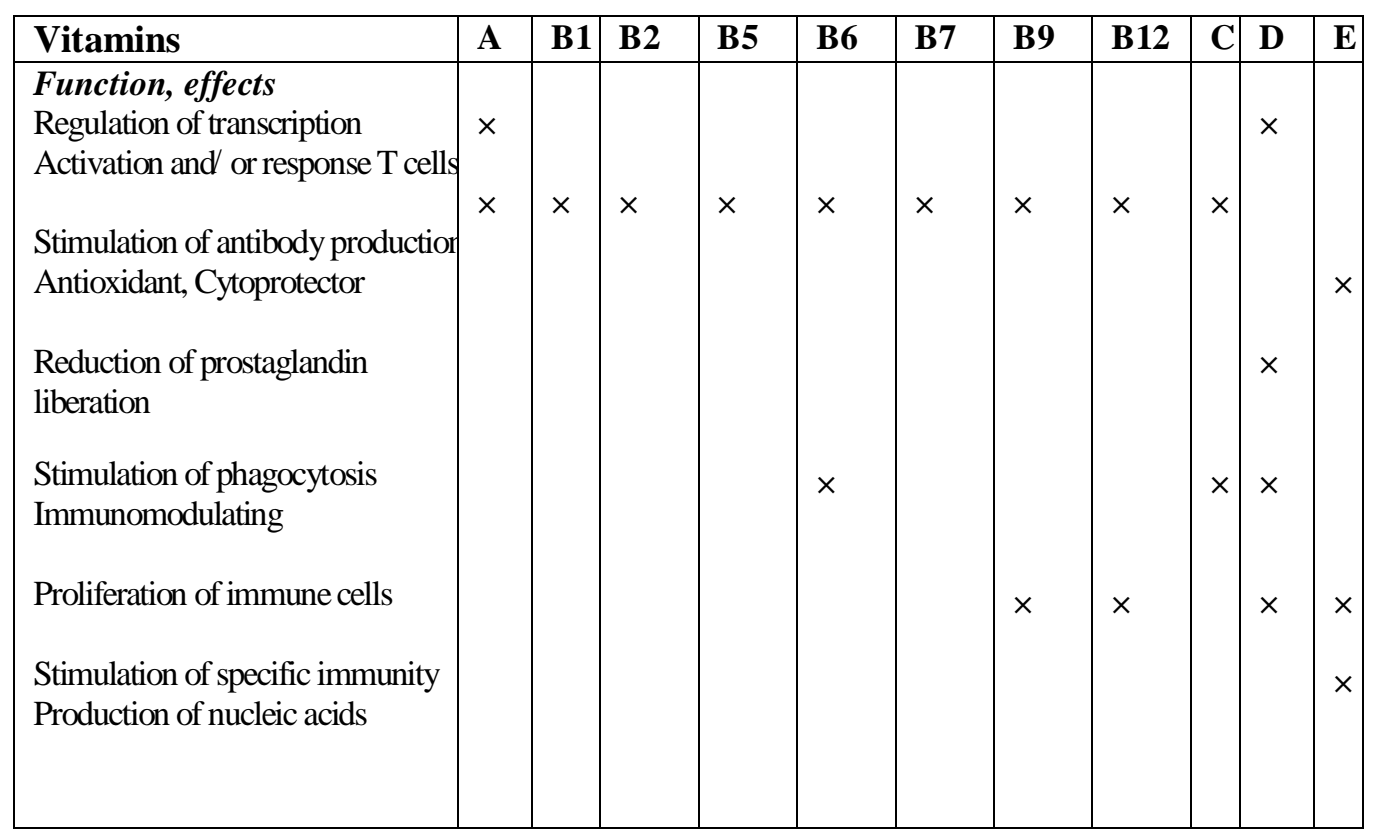

Vitamins: A: retinol, B1: Thiamin, B2: Riboflavin, B5: Pantothenic acid, B6: Pyridoxine, B7: Biotin, B9: Folic acid, B12: Cyanocoblamine, C: Ascorbic acid. 
Table (3). Recommended dietary mineral concentrations for rabbits of different physiological status (Feed contains 89\% dry matter, McWilliams, 2001).

\begin{tabular}{|l|c|c|c|c|c|}
\hline Minerals & $\begin{array}{c}\text { Growing } \\
\text { Rabbits } \\
\text { (4 To 12 } \\
\text { Weeks) }\end{array}$ & $\begin{array}{c}\text { Lactating } \\
\text { Does and Kits } \\
\text { before } \\
\text { Weaning }\end{array}$ & $\begin{array}{c}\text { Pregnant } \\
\text { Doe }\end{array}$ & Males & $\begin{array}{c}\text { Fatteners } \\
\text { and Non- } \\
\text { Pregnant } \\
\text { Does }\end{array}$ \\
\hline Calcium & $0.4 \%$ & $1.10 \%$ & $0.80 \%$ & $0.40 \%$ & $1.10 \%$ \\
\hline Phosphorus & $0.3 \%$ & $0.5 \%-0.8 \%$ & $0.37 \%-$ & $0.3 \%$ & $0.3 \%-0.8 \%$ \\
\hline Potassium & $0.6 \%$ & $0.9 \%$ & $0.9 \%$ & $*$ & $0.9 \%$ \\
\hline Sodium & $0.3 \%$ & $0.3 \%$ & $0.3 \%$ & $*$ & $0.3 \%$ \\
\hline Chlorine & $0.3 \%$ & $0.3 \%$ & $0.3 \%$ & $*$ & $0.3 \%$ \\
\hline Magnesium & $0.03 \%$ & $0.04 \%$ & $0.04 \%$ & $*$ & $0.04 \%$ \\
\hline Sulphur & $0.04 \%$ & $*$ & $*$ & $*$ & $0.04 \%$ \\
\hline Cobalt & $0.1 \mathrm{ppm}$ & $0.1 \mathrm{ppm}$ & $*$ & $*$ & $0.1 \mathrm{ppm}$ \\
\hline Copper & $5.0 \mathrm{ppm}$ & $5.0 \mathrm{ppm}$ & $*$ & $*$ & $5.0 \mathrm{ppm}$ \\
\hline Zinc & $50.0 \mathrm{ppm}$ & $70.0 \mathrm{ppm}$ & $70.0 \mathrm{ppm}$ & $*$ & $70.0 \mathrm{ppm}$ \\
\hline Iron & $50.0 \mathrm{ppm}$ & $100.0 \mathrm{ppm}$ & $50.0 \mathrm{ppm}$ & $50.0 \mathrm{ppm}$ & $100.0 \mathrm{ppm}$ \\
\hline Manganese & $8.5 \mathrm{ppm}$ & $2.5 \mathrm{ppm}$ & $2.5 \mathrm{ppm}$ & $2.5 \mathrm{ppm}$ & $8.5 \mathrm{ppm}$ \\
\hline Iodine & $0.2 \mathrm{ppm}$ & $0.2 \mathrm{ppm}$ & $0.2 \mathrm{ppm}$ & $0.2 \mathrm{ppm}$ & $0.2 \mathrm{ppm}$ \\
\hline
\end{tabular}

* Indicates that dietary levels were not established.

Table (4) Recommended dietary vitaminlevelsfor rabbits (mg kg- ${ }^{1}$ ).

\begin{tabular}{|l|c|c|}
\hline Rabbit status & NRC, 1977 & Lebas, 2004 \\
\hline Growing- fattening: & 0.58 & 6 \\
Vitamin A (m IU) & - & 1 \\
Vitamin D & 40 & 30 \\
Vitamin E & - & 1 \\
Vitamin k3 & 180 & 50 \\
Niacin & 39 & 2 \\
Pyridoxine & - & 2 \\
Thiamine & - & 6 \\
Riboflavin & - & 5 \\
Folic acid & - & 20 \\
Pantothenic acid & - & 0.01 \\
Cyanocoblamine (Vitamin B12) & 1200 & 200 \\
Choline & - & - \\
Biotin & - & - \\
Lactating does & - & 10 \\
Vitamin A (m IU) & - & 1 \\
Vitamin D (m IU) & 30 & 50 \\
Vitamin E & - & 2 \\
Vitamin k3 & & \\
\hline
\end{tabular}




\begin{tabular}{|l|c|c|}
\hline Niacine & - & 40 \\
Pyridoxine & - & 2 \\
Thiamine & - & 2 \\
Riboflavin & - & 6 \\
Folic acid & - & 5 \\
Pantothenic acid & - & 20 \\
Cyanocoblamine (Vitamin B12) & - & 0.01 \\
Choline & - & 100 \\
\hline
\end{tabular}

\section{Feed additives:}

\section{1-Feed enzymes:}

Exogenous enzymes not only influence on the absorption of nutrients, but also produce nutrients for specific populations of beneficial bacteria through their action (Apajalahti et al., 2004, Adeola and Cowieson, 2011 and Bedford and Cowieson, 2012).The use of enzymes as feed additives has not been extensively studied in the rabbit (Falcao-e-Cunha et al., 2007). Rabbits are very efficient in the utilization of nutrients (except for fibre), probably because of coprophagy (Marounek et al., 1995; Guidenne and Lacois, 2005). Makkar and Singh (1987) found that the activity of proteases and amylases was higher in the caecum of rabbits than in the rumen. Marounek et al. (1995) reported that the caecal contents of 4-week old rabbits contained most of the total activity of pectinase (0.43), amylase $(0.45)$, lactase (0.57), Xylanase (0.65), cellulase (0.69), $\beta$-glucosidase $(0.70)$ and urease $(0.80)$ present in the rabbit digestive tract, and that these values increased with age. Consequently, the beneficial effects of carbohydrases supplementation are expected to be very limited.The inclusion of proteases in the diet reduced rabbit mortality during the first 14 days of the fattening period (Garcia-Palomares et al., 2006a and b). At present, the addition of exogenous carbohydrases and protease enzymes to rabbit feeds should be limited to diets for the first 14 days after weaning. Similarly, the use of phytases may have some merits in rabbit feeds (Gutierrez et al., 2000), although the benefits are probably less than those observed for other nonruminant species.

\section{2- Probiotics:}

Probiotics are defined as "a live microbial feed supplement which beneficially affects the host animal by improving its intestinal balance" (Fuller, 1989 and Alexandre et al, 2014). Most organisms used in probiotics are strains of gram positive bacteria of the genera Bacillus (B. subtilis), Enterococcus (E. faecium), Lactobacillus (L.acidophilus), Bifidobacteria 
(B. lactis), Streptococcus (S. infanarius), some yeasts or fungi such as Saccharomyces cerevisae.

The probiotics mode of action is by "competitive exclusion". Probioticsareconsideredtobeabletodestroypathogenicmicroorganismsbyprod ucinganti-microbial compounds such as bacteriocins and organic acids, improve gastrointestinal microbial environment by a dherencetoint estinal mucosa, thereby preventing attachment of pathogens and competing with pathogens for nutrients, stimulate the intestinal immune responses and improve the digestion and absorption of nutrients (Anadon et al,2006 and Ewuola et al, 2011).

\section{3-Prebiotics:}

Prebiotics are non- digestible (by the host) feeding redients that have a beneficial effect through their selective metabolism in the intestinal tract (Gibson et al, 2004). Prebiotics include oligosaccharides such as fructooligosaccharide (FOS), mannan-oligosaccharide (MOS), polysaccharides, natural plant extracts, etc. Prebiotics can selectively proliferate intestinal bacteria, promote immune functions, show anti-viral activity, promote mineral absorption and regulate metabolism. The applications of prebiotics as feed additives began in the late 1980s. China began touse them in the late 1990s. Currently, the most promising prebiotics are multi- function aloligosaccharides and acidifiers (Radwan and Abd Elkhalek, 2007, ElHanoon et al, 2007, Bonai et al, 2008and Attia et al,2013).

\section{4-Synbiotics:}

Synbiotics are mixture of probiotics and prebiotics, and thus have the dual role of them (Andersson et al, 2001). There are some reports on the beneficial effects of synbiotics on the physiological and biochemical indexes of rabbits and piglets, including the enhancement of immune function, the improvement of average daily gain and digestibility, there duction of diarrhea and mortality(Davis et al, 2004,Gaggiaetal,2010 and Ewuola et al, 2011).

\section{5-Plant extracts}

Plant materials are used widely in traditional systems of medicine (Savoia,2012). Plant extracts, also known a sphytobiotics, have been exploited in animal nutrition, particularly for their antimicrobial, antiinflammatory, anti-oxidative, and anti-parasitic activities (Vondruskova et al., 2010; Hashemi and Davoodi, 2011). Many plants have beneficial multifunctional properties derived from their specific bioactive components. 
Biologically active constituents of plants are mostly second arymeta bolites, such as terpenoids (mono-and sesquiter penes, steroids, etc.), phenolics (tannins), glycosides, and alkaloids (present as alcohols, aldehydes, ketones, esters, ethers, lactones, etc. (Huyghebaert et al, 2011). Among 109 new antibacterial drugs, approved in the period of 1981 2006, 69\% originated from natural products, and $21 \%$ of the antifungal 1 drugs were natural derivatives or compounds of natural products (Newman,2008). Plant extracts are generally considered safe and effective against certain bacteria. They are extensively used in feed as growth promoters and health protectants (Hashemi and Davoodi, 2011; Abreu et al., 2012), particularly in Asian, African, and South American countries, and are gradually used in developed countries in recent years.

\section{6-Organic acids:}

Organic acids are considered to be any organic carboxylic acid of the general structure R-COOH (including fatty acids and amino acids). Not all of these acids have effects on gut microflora. Organic acids with specific antimicrobial activity are short-chain acids (C1-C7) and they are widely distributed in nature as normal constituents of plants or animal tissues (formic, acetic, propionic, butyric, lactic, sorbic, fumaric, malic, citric and benzoic acid). They are also formed through microbial fermentation of carbohydrates mainly in the large intestine. Organic acids or acidifiers are widely used as feed additives for the control of pathogenic bacteria (Hansen et al., 2007). The mode of actions of organic acids may be includes reducing the digesta $\mathrm{pH}$ value in the gastrointestinal tract (GIT), regulating the balance of microbial populations in the gut, stimulating the secretion of digestive enzyme and promoting the growth and recovery of the intestinal morphology (Papatsiros et al, 2012). Moreover, acidifiers appear to have antimicrobial activity, by controlling the bacterial populations in the gut, increasing activity of proteolytic enzymes, and inhibiting the proliferation of pathogenic bacteria. Dietary organic acids can actually become an alternative solution to antibiotics, in order to improve health status and performance of rabbits and other monogastric animals (Skrivanovà and Marounek, 2007 and Cardinali et al, 2008).

Conclusively, the interactions between nutrients, immunology, and disease resistance are extremely complex. There are many factors that could affect an animal's response to nutrients feeding such as the duration and concentration of nutrients in the diet, physiological status of an animal (pregnancy, suckling, growing), the absence or presence of dietary antagonists, environmental factors, and the influence of stress on nutrients metabolism. 
Insufficient contents of micronutrients in animal diets are related with low disease resistance. A balanced supply of micronutrients such as vitamins $\mathrm{E}, \beta$ - Carotenoids, Vitamin $\mathrm{A}$, Vitamin $\mathrm{C}$ and the trace elements zinc $(\mathrm{Zn})$, Copper $(\mathrm{Cu})$, selenium $(\mathrm{Se})$, Manganese $(\mathrm{Mn})$, Cobalt $(\mathrm{Co})$, Iron $(\mathrm{Fe})$ are of great importance for proper functioning of host defense mechanism.Some feed additives such as probiotics, prebiotics, enzyme preparations and organic acids could improve the immune response and disease resistance in rabbits.

Subclinical or marginal deficiency of micronutrients (trace minerals or vitamins)represent larger problem than acute deficiency, because specific clinical symptoms are not evident to allow the producer to recognize the deficiency.Subclinical trace minerals or vitamins deficiencies will adversely affect immunity, reproduction and growth before clinical deficiency symptoms are observed.

The amount of research done on the effect of nutrition on immune function in rabbits is very little, so it is difficult now to propose actual dietary values for stimulating the immune defense of rabbits. However, the nutritionists can use the available dataof fiber, fats (namely the quantity and nature of fatty acids), vitamin $\mathrm{E}$ and selenium and the interaction between themto offer the most interesting in this concern. The work should concentrate on the rabbit at weaning time, because this is the most critical period for young rabbits to infect by the digestive diseases.

\section{REFERENCES}

Abreu, A. C., McBain, A. J. and Simoes, M (2012).Plants as sources of new Anti microbials and resistance-modifying agents .Nat. Prod. Rep. 29, 1007-1021. doi: 10.1039/c2 np 20035j.

Adeola, O., and Cowieson, A. J. (2011). Board-invited review: opportunities and challenges in using exogenous enzymes to improve non ruminant animal production. J. Anim.Sci. 89, 31893218.doi:10.2527/jas.2010-3715.

Alexandre,Y.,LeBlay,G.,Boisrame-Gastrin,S.,LeGall,F.,Hery-Arnaud, G., Gouriou, S., et al (2014). Probiotics: A new way to fight bacterial pulmonary infections. Med. Mal. Infect. 44, 9-17.doi:10.1016/j.medmal. 2013. 05.001.

Anadon, A., Martinez Larranaga, M.R andAranzazu Martinez, M (2006). Probiotics for animal nutrition in the European Union. Regulation and safety assessment. Regul. Toxicol. Pharmacol. 45, 9195.doi:10.1016/j.yrtph.2006.02.004 
Andersson, H.,A sp, N.-G., Bruce,A., Roos, S., Wadstrom,T., and Wold, A (2001). Health effects of probiotics and prebiotics: A literature review on human studies. Scand. J. Nutr. 45, 58-75.

Apajalahti, J., Kettunen, A., and Graham, H (2004). Characteristics of the gastro-intestinal microbial communities, with special reference to chickens. World Poult. Sci. J. 52, 223-232 .doi: 10.1079/ WPS 20040017.

Attia,Y. A., El-Hanoun, A. M., Bovera, F. Monastra, G., El-Tahawy,W. S. and. Habiba,H. I (2013). Growth performance, carcass quality, biochemical and haematological traits and immune response of growing rabbits as affected by different growth promoters. J. Animal Physiology\&Animal Nutrition, DOI: 10.1111/jpn.12056.

Battaa, A. M.,El-Neney and El-Kholy K. H(2014).Effect of natural additive (bee pollen) on immunity and productive and reproductive performances in rabbits. 1-Growth performance, digestive and immune responses in growing rabbits. Egypt. Poult. Sci. Vol 34, (II),pp. 579-606.

Bedford,M.R., and Cowieson, A. J. (2012). Exogenous enzymes and their effects on intestinal microbiology.Anim.FeedSci.Technol. 173, 7685.doi: 10.1016/j.anifeedsci.2011.12.018. www.frontiersin.org .

Bonai, A.; Szendro, Z.; Maertens, L.; Matics, Z.; Febel, H.; Kametler, L.; Tornyos, G.; Horn, P.; Kovacs, F., Kovacs, M. (2008). Effect of in supplementation on caecal microflora and fermentation in rabbits.The $9^{\text {th }}$ World Rabbit Congress., June10-13, Verona, Italy.

Broome C.S., McArdle F., Kyle J.A., Andrew F., Lowe N.M., Hart C.A., Arthur J.R., Jackson M.J. (2004): An increase in selenium intake improves immune function and poliovirus handling in adults with marginal selenium status. American Journal of Clinical Nutrition, 80, 154-162.

Calder P.C. (1998). Dietary fatty acids and the immune system. Nutr. Rev.56: S70-S83.

Calder P.C. (2006): Branched-chain amino acids and immunity. The Journal of Nutrition, 136, 288S-293S.

Carabano, $\mathbf{R}$ and Piquer, $\mathbf{J}$ (1998). The digestive system of the rabbit. IN: de Blas C, Wiseman J, The Nutrition of the Rabbit. New York, NY: CABI Publishing. p. 1-16.

Chapkin R.S., McMurray D.N and Jolly C.A (2000). Dietary n-3 polyunsaturated fatty acids modulate T-lymphocyte activation: clinical relevance in treating diseases of chronic inflammation. In: Nutrition and immunology: principles and practices. M.E. Gerswhin, J.B. German and C.L. Keen Eds. Humana press, Totowa, USA, Chap10: 121-134. 
Cardinali R., Rebollar P.G., Dal Bosco A., Cagiola M., Moscati L., Forti K., Mazzone P., Scicutella N., Rutili D., Mugnai $C$ and Castellini C(2008). Effect of dietary supplementation of organic acidsand essential oils on immune function and intestinalcharacteristics of experimentally infected rabbits. The $9^{\text {th }}$ World Rabbit Congress - June 10-13, Verona Italy.

Carroll, J.A. and N.E. Forsberg (2007). "Influence of stressand nutrition on cattle immunity." Vet. Clin. Food Anim. 23: 105-49.

Chamorro, S., Gomez-Conde, M.S., Centeno, C., Carabano, R. and de Blas, J.C. (2007). Effect of dietary sodium on digestibility of nutrients and performance in growing rabbits. World Rabbit Science 15, 141-146.

Chiericato, G.M. and Rizzi, C. (2004). Study of the effect of the dietary mineral content on the reproductive performance of rabbits of both sexes and on the zootechnical performance of their litters. Rivista diConiglicoltura 41, 44-48.

Csiro, Council of Science and Industrial Research Organization (2001). Diet improves immunity to gut diseases. CSIRO Information Sheet: Victoria: Australia.

Cunningham-Rundles S., Mc Neeley D.F., Moon A. (2005). Mechanisms of nutrient modulation of the immune response. Journal of Allergy and Clinical Immunology, 115, 1119-1128.

Davis, S.L. 1998. Environmental modulation of the immune system via the endocrine system. Domestic Animal Endocrinology. Vol. 15(5):283-289, Elsevier Sci. Inc.

Davis, M. E., D. C. Brown, C. V. Maxwell, Z. B. Johnson, E. B. Kegley, and R.A. Dvorak. (2004). Effect of phosphorylated mannans and pharmacological additions of zinc oxide on growth and immune competence of weanling pigs. J. Anim. Sci. 82:581-587.

De Blas C and Wiseman J. 2010. Nutrition of the rabbit. The $2{ }^{\text {nd }}$ edition, CABIPublishing, Wallingford,UK. 344 pp.

DeCuypere, J. A. and N. A. Dierick, 2003. The combined use of triacylglycerols containing medium-chain fatty acids and exogenous lipolytic enzymes as an alternative to in-feed antibiotics in piglets: concept, possibilities and limitations. An overview. Nut. Res. Reviews, $16,193-209$.

Drouet-Viard F and Fortun-Lamothe L. 2002. Review : the organization and functioning of the immune system : particular features of the rabbit. World Rabbit Sci. 10 (1) : 15-24.

Eiben, C.; Gippert, T.; Godor-Surmann, K.; Kustos, K (2008). Feed additives as they affect the fattening performance of rabbit. 9th World Rabbit Cong., June 10-13, Verona, Italy. 
El-Hanoun, A. M.; El-Saieed, H. A.; El- Sbeiy, M. S.; Kamel, K.I (2007). Effect of bee pollen supplementation on some productive, reproductive and biochemical traits of growing male rabbits during winter and summer seasons.5th Inter. Conf. on Rabbit Prod. In Hot Climate, 4-7 December, Hurghada, Egypt.417-433.

Erickson, K. L., E.A. Medina, and N.E. Hubbard ( 2000). Micro nutrients and Innate Immunity."J. Infect. Diseases. 182 (Suppl 1): S5-10.

Evoy D., Lieberman M.D., FaheyT.J.and Daly J.M (1998). Immunonutrition: the role of arginine. Nutr.14: 611-7.

Ewuola, E. O., Amadi, C. U. and Imam, T. K (2011). Performance evaluation and nutrient digestibility of rabbits fed dietary prebiotics, probiotics and symbiotics. International Journal of Applied Agricultural and Apicultural Research, 7 (1\&2): 107-117.

Falcao-e-Cunha, L., Castro-Solla, L., Maertens, L., Marounek, M., Pinheiro, V., Freire, J. and Mourao, J.L.(2007). Alternatives to antibiotic growth promoters in rabbit feeding: a review. World Rabbit Science, 15:127-140.

Fassbinder-Orth, C. A. and W. H. Karasov. 2006. Effects of feed restriction and re-alimentation on digestive and immune function in the Leghorn Chick. Poultry Science, 85:1449-1456.

Fekete S.,Tamas J.,Vanyi A., Glavits R., Bata A. (1989): Effect of T-2 toxin on feed intake, digestion and pathology of rabbits. Laboratory Animal Science, 39, 603-606.

Fekete,S.G and Kellems, R.O (2007). Interrelationship of feeding with immunity and parasitic infection: a review. Veterinarni Medicina, 52, 2007 (4): 131-143.

Fortun-Lamothe, L. and Drouet-Viard (2002). Review: $\Pi$ - Diet and immunity: Current state of knowledge and research prospects for the rabbits. World Rabbits Science, Vol.10 (1): 25-39.

Forthun-Lamothe $\mathbf{L}$ and Boullier S. (2004).Interaction between gut microflora and digestive mucosal immunity and strategies to improve digestive health in young rabbits.In: Proc., 8 th World Rabbit Congress, Puebla, Mexico, 1035-1067.

Fraker P.J., King L.E., Laakkoo T., Volimer T.L. (2000): The dynamic link between the integrity of the immune system and zinc status. The Journal of Nutrition, 130, 1399S-1406S.

Fuller, R. (1989). Probiotics in man and animals.Journal Appl. Bacteriol.,66:365 - 378.

Klasing, K. C. 1998. Nutritional modulation of resistance to infectious diseases. Poultry. Sci., 77: 1119-1125. 
Gaggia, F., Mattarelli, P and Biavati, B.(2010). Probiotics and prebiotics in animal feeding for safe food production. Int. J. Food Microbiol. 141(Suppl.1),S15-S28. doi: 10.1016/j.ijfoodmicro.2010.02.031.

Gallois M., Gidenne T., Forthun-Lamothe L., Le Huerou-Luron I and Lallès J.P. (2005). An early stimulation of solid feed intake slightly influences the morphological gut maturation in the rabbit. Reprod. Nutr. Dev. 45, 109-122.

Garcia-Palomares, J., Carabano, R., Garcia- Rebollar, P., de Blas, C., Corujo, A. and Garcia Ruiz, A.I., (2006a).Effects of a dietary protein reduction and enzyme supplementation on growth performance in the fatteningperiod. World Rabbit Science 14, 231-236.

Garcia-Palomares, J., Carabano, R., Garcia-Rebollar, P., de Blas, J.C. and Garcia, A.I. (2006b).Effects of dietary protein reduction during weaning on the performance of does and suckling rabbits.World RabbitScience 14, 23-26.

Genton L. and Kudsk K. A.(2003). Interactions between the enteric nervous system and the immune system: role of neuropeptides and nutrition. Am. J. Surg. 186: 253-258.

Gidenne T, Pinheiro V andCunha(1998). Consequences of a dietary fiber deficiency on adult rabbit digestion and rate of passage: first results. Proceedings of the 7th French Rabbit Days, May 1998, Lyon, France.

Gidenne T (2000). Recent advances in rabbit nutrition: emphasis on fiber requirements :A review. World Rabbit Science, 8(1).

Guidenne, T. and Licois, D. (2005). Effect of a high fibre intake on the resistance of the growing rabbit to an experimental inoculation with an enteropathogenic strain of Escherichia coli.Animal Science 80, 281-288.

Gutierrez, I., Garcia, J., Carabano, R., Mateos, G.G. and de Blas, J.C. (2000). Effect of exogenous phytase on phosphorus and nitrogen digestibility in growing- finishing rabbits. In: Blasco, A. (ed.)..Proceedings of $7^{\text {th }}$ World Rabbit Congress, Valencia. Valencia University Publications, Valencia, Spain, pp. 277-281.

Guyue Cheng, HaihongHao, ShuyuXie , XuWang, Menghong Dai, Lingli Huang 2,3 and Zonghui Yuan (2014). Antibiotic alternatives: the substitution of antibiotics in animal husbandry: Review article. Frotiers in Microbiology, doi: 10.338 fmicb.2014.00217.

Hansen C.F., Riis A.L., Bresson S., Hojbjerg O and Jensen B.B. (2007). Feeding organic acids enhances the barrier function against pathogenic bacteria of the piglet stomach. Livestock Science, doi: 10.1016/j.livsci.2007.01.059.

Hashemi, S.R and Davoodi, H 2011).Herbal plants and their derivatives as growth and health promoters in animal nutrition. Vet. Res. Commun. 35, 169-180. doi: 10.1007/s11259-010-9458-2. 
Huyghebaert, G., Ducatelle, R and Van Immersee 1, F (2011).An up date on alternative to antimicrobial growth promoters for broilers. Vet.J. 187, 182-188.doi:10.1016/j.tvj1.2010.03.003.

Kerti, A., Bardos, L., Deli, J. and Olah, P. (2005). Relationship of retinoid and carotenoid metabolism with caecotrophy in rabbits. Acta Veterinaria Hungarica, 53, 309-318.

Kidd, M.T (2004). Nutritional modulation of immune function in broilers. Poultry Science, 83: 650 - 657.

Klasing, K.C.and Leshchincky, T.V (2000). Interactions between nutrition and immunity: Lesson from animal agriculture. In: Nutrition and immunology: principles and practices. M.E.Gersulin, S.B.German and C.L.Keen Eds. Humana press, Totowa, USA, chap.30, 363-374.

KolbE(1997). Vitamins and the immune system.F. Hoffmann-La Roche Ltd., Bassel, Switzerland, 74pp.

Korver, D. R(2012). Implications of changing immune function through nutrition in poultry. Anim. Feed Sci. Technol.,173,54-64.

Koski K.G., Su Z., Scott M.E. (1999). Energy deficits suppress both systemic and gut immunity during infection. Biochemical and Biophysical Research Communications, 264: 796-801.

Lai Y.N., Yeh S.L., Lin M.T., Shang H.F., Yeh C.L and ChenW.J (2004). Glutamine supplementation enhances mucosal immunity in rats with gutderived sepsis. Nutr., 20: 286-291.

LeBlanc S. J., K. D. Lissemore, D. F. Kelton, T. F. Duffield, and K. E. Leslie. 2006. Major advances in disease prevention in dairy cattle. $J$. Dairy Sci., 89:1267-1279.

Lebas, F (2000). Vitamins in rabbit nutrition: Literature review and recommendation. World Rabbit Science,8 (4), 185- 192.

Lebas, F. (2004). Reflections on rabbit nutrition with special emphasis on feed ingredients utilization. In: Becerril, C.M. and Pro, A. (ed) Proceedings of the 8th World Rabbit Congress, Puebla. Colegio de Postgraduados, Montecillo, Spain, pp. 686-736.

Makkar, H.P.S. and Singh, B. (1987). Comparative enzymatic profiles of rabbit caecum and bovine rumen content.Journal of Applied Rabbit Research 10, 172-174.

Marai, I.F.M., Habeeb, A.A.M. and Gad, A.E. (2005). Tolerance of imported rabbits grown as meat animals to hot climate and saline drinking water in the subtropical environment of Egypt. Animal Science 81,115-123.

Marounek, M., Vovk, S.J. and Skrivanova, V. (1995). Distribution of activity of hydrolytic enzymes in the digestive tract of rabbits. British Journal of Nutrition 73, 463-469. 
McWilliams, D.A (2001). Nutritional Pathology in Rabbits: Current and Future Perspectives. Ontario Commercial Rabbit Growers Association (OCRGA) Congress.

Miles,M.A. and Calder,P.C (1998).Modulation of immune function by dietary fatty acids. Proc.Nut.Soc.,57,277-292.

Millet, S. and Maertens, L (2011). TheEuropeanbanonantibioticgrowthpromotersinanimalfeed:from challen gestoopportunities. Vet.J. 187, 143144.doi: $10.1016 / j . t v j 1.2010 .05 .001$.

Miura S., Tsuzuki Y., Hokari R. and Ishii H.(1998). Modulation of intestinal immune system by dietary fat intake: Rlevance to Crohn's disease. J. Gastroenterol. Hep.13:1183-1190.

Newman,D. J. (2008). Natural products as lead stop otential drugs: an old processor the new hope for drug discovery? J. Med.Chem. 51, 25892599.doi:10.1021/jm0704090.

NRC (1977). Nutrient Requirements of Rabbits.National Academy of Science, National Research Council, Washington, DC, USA.

Oppenheimer S.J. (2001). Iron and its relations to immunity and infectious diseases.The Journal of Nutrition, 131, 616S-635S.

Pablo, M.A. and Cienfuegos, G.A (2000). Modulatory effects of dietary lipids on immune system function. Immunology \& cell Biology, 78, 31-39.

Papatsiros, V. G, Christodoulopoulos, G. and Filippopoulos, L. C (2012). The use of organic acids in diets of monogastric animals (swine and rabbits).Journal of Cell and Animal Biology Vol. 6(10), pp. 154-159.

Peeters J.E. (1988). Recent advances in intestinal pathology of rabbits and further perspectives. In: Proc. $4^{\text {th }}$ World Rabbit Congress, Pathology Proceeding, pp. 293-315.

Pinelli-Saavedra A. (2003).Vitamin E in immunity and reproductive performance in pig. Reproduction and Nutrition Development, 43, 397-408.

Pinheiro V and Gidenne T (2000). Substitution of Wheat by potato starch for growing rabbits: Effect on performances, digestion and health. Proc 7th World Rabbit Congress, 4-7July, Valencia, Spain, Vol C: 391-398.

Radwan, N. L and Abdel-Khalek, A. M., 2007: Response of summer stressed growing rabbits to some dietary growth promoters. In: Proc. of the $13^{\text {th }}$ Inter. Cong. In Animal Hygiene, Tartu, Estonia, 17-12 June. Vol. 1: pp. 350-358.

Rashwan A.A. and Marai I.F (2000). Mortality in young rabbits: A Review .World Rabbit Science, 8(3), 111-124.

Ravindran, V., and Son, J.H. (2011).Feed enzyme technology: present status and future developments. Recent Pat. Food Nutr. Agric. 3, 102109.doi: $10.2174 / 2212798411103020102$.

Redmond H.P., Stapleton P.P., Neary P and Bouchier-Hayes D. (1998). Immunonutrition: the role of taurine. Nutr.14: 599-604. 
Remois G., Abiven N., Ledan L., Lafargue-Hauret P. and Bourdillon A. (2000). Effect of dietary fiber and energy content on mortality and growth performances of rabbits in case of epizootic rabbit enterocolitis.The Seventh World Rabbit Congress, July 2000, Valence, Spain.

Savoia, D (2012). Plant-derived antimicrobial compounds : alternatives to antibiotics. FutureMicrobiol.7, 979-990.doi:10.2217/fmb.12.68

Stanton, T. B. (2013). A call for anti biotic alternatives research. TrendsMicrobiol.21, 111-113. doi:10.1016/j.tim.2012.11.002.

Scrimshaw N.S and San Giovanni J.P.(1997). Synergism of nutrition, infection, and immunity: an overview. Am. J. Clin. Nutr.66: 464S-477S.

Seal, B. S., Lillehoj, H. S., Donovan, D. M., and Gay, C.G (2013). Alterna tives to antibiotics: a symposium on the challenges and solutions for animal production. Animal Health Res. Rev. 14, 78-87. doi:10.1017/ S14662523130 00030.

Shyam, S.P and Avijit, D (2015).Nutrition in health and immune function of ruminant. The Indian Journal of Animal Sciences, 85 (2): 103- 112.

Skrivanová E., Marounek M.(2007). Influence of $\mathrm{pH}$ on antimicrobial activity of organic acids against rabbit enteropathogenic strain of Escherichia coli. Folia Microbial (Praha), 52, 70-72.

Vondruskova,H.,Slamova,R.,Trckova,M.,Zraly,Z.,andPavlik,I.(2010).Alt erna-tivesto antibiotic growth promoters in prevention of diarrhoea in weaned piglets: a review. Vet.Med. 55, 199-224.

Yaqoob $P$ (2003). Fatty acids as gatekeepers of immune cell regulation.Trends immunol.24: 639-645.

Ziboh V. A (2000). Nutritional modulation of inflammation by polyunsaturated fatty acids /ecosanoids. In: Nutrition and Immunology: Principles And Practices. M.E. Gerswhin, J.B. German and C.L. Keen Eds. Humana press, Totowa, USA. Chap13: 157-170. 